\title{
Mycobacterium tuberculosis subsp. caprae subsp. nov.: a taxonomic study of a new member of the Mycobacterium tuberculosis complex isolated from goats in Spain
}

\author{
Alicia Aranaz, ${ }^{1}$ Ernesto Liébana, ${ }^{1}$ Enrique Gómez-Mampaso, ${ }^{2}$ \\ Juan C. Galán, ${ }^{2}$ Debby Cousins, ${ }^{3}$ Arturo Ortega, ${ }^{4}$ Jesús Blázquez, ${ }^{2}$ \\ Fernando Baquero, ${ }^{2}$ Ana Mateos, ${ }^{1}$ Guillermo Súarez ${ }^{1}$ \\ and Lucas Domínguez ${ }^{1}$
}

\footnotetext{
1 Departamento de Patología Animal I (Sanidad Animal), Facultad de Veterinaria, Universidad Complutense de Madrid, 28040 Madrid, Spain

2 Servicio de Microbiología, Hospital Ramón y Cajal, 28034 Madrid, Spain

3 Australian Reference Laboratory for Bovine Tuberculosis, Agriculture Western Australia, South Perth 6151, Australia

4 Centro Nacional de Investigación Clínica y $\mathrm{M}$. P., Hospital Carlos III, 28029 Madrid, Spain
}

\begin{abstract}
Author for correspondence: Lucas Domínguez. Tel: +34 91 3943721. Fax: + 34913943908 e-mail: alaranaz@eucmax.sim.ucm.es
\end{abstract}

Isolates from the Mycobacterium tuberculosis complex cultured from caprine pathological tissue samples were biochemically and genetically characterized. The isolates were negative for nitrate reduction and niacin accumulation, they weakly hydrolysed Tween 80 , were sensitive to pyrazinamide $\left(50 \mu \mathrm{g} \mathrm{ml}^{-1}\right)$ and were resistant to 1 and $2 \mu \mathrm{g}$ tiophene-2-carboxylic acid hydrazide $\mathrm{ml}^{-1}$ but not to 5 or $10 \mu \mathrm{g}$ tiophene-2-carboxylic acid hydrazide $\mathrm{ml}^{-1}$. Sequencing of the pncA gene revealed a polymorphism characteristic of $M$. tuberculosis, whereas oxyR, katG and gyrA sequences were characteristic of Mycobacterium bovis. The fingerprinting patterns obtained with IS6110, direct repeats and polymorphic G+C-rich sequence-associated RFLP and direct variable repeat-spacer oligonucelotide typing (spoligotyping) segregated these isolates from the other members of the complex. The results of this testing, together with the repeated association of this micro-organism with goats, suggest that a new member of this taxonomic complex not matching any of the classical species had been identified. This unusual mycobacterium may play a role in the epidemiology of animal and human tuberculosis in Spain. The name Mycobacterium tuberculosis subsp. caprae subsp. nov. is proposed for these isolates. The type strain of Mycobacterium tuberculosis subsp. caprae subsp. nov. is gM-1 $^{\top}$ ( = CIP 105776').

Keywords: Mycobacterium tuberculosis subsp. caprae subsp. nov., Mycobacterium tuberculosis complex, tuberculosis, goats

\section{INTRODUCTION}

The Mycobacterium tuberculosis complex consists of a highly related group of acid-alcohol-fast bacilli which are human and animal pathogens. It comprises five classical species. M. tuberculosis (sensu stricto) infects

\footnotetext{
Abbreviations: BCG, Bacillus Calmette-Guérin; DR, direct repeat; DVR, direct variable repeat; IS, insertion sequence; ITS, internal transcribed spacer; PGRS, polymorphic G+C-rich sequence; PZA, pyrazinamide; spoligotyping, spacer oligonucleotide typing; $\mathrm{TCH}$, tiophene-2-carboxylic acid hydrazide.

The EMBL accession number for the 16S rRNA gene sequence of strain gM$1^{\top}$ is AJ131120.
}

human and non-human primates, and has also been found in dogs and cats (Snider, 1971; Liu et al., 1980; Clercx et al., 1992; Aranaz et al., 1996b), pigs (Kleeberg \& Nel, 1969), birds (Hoop et al., 1996) and some wild animals (Thoen, 1994; Michalak et al., 1998). Mycobacterium bovis (Karlson \& Lessel, 1970), the causative agent of bovine tuberculosis, infects a wide range of domestic and wild hosts (Collins \& Grange, 1983; O'Reilly \& Daborn, 1995). Bacillus Calmette-Guérin (BCG) is a vaccine strain derived from $M$. bovis. Mycobacterium africanum, described by Castets et al. (1969), is a rather heterogeneous group of strains responsible of human tuberculosis in Equatorial Africa, and has properties that are in- 
termediate between the aforementioned species; it also infects primates (Thorel, 1980), cattle and pigs (Alfredsen \& Saxegaard, 1992). Finally, Mycobacterium microti (Reed, 1957) is the 'vole bacillus' described by Wells \& Oxon (1937). It is found mainly in small rodents, but infection has also been recorded in cats, pigs (Huitema \& Jaartsveld, 1967) and llamas (Pattyn et al., 1970).

Extensive studies based on DNA homology have reported a 95-100\% DNA relatedness between members of the complex, suggesting that these organisms belong to the same species (Baess, 1979; Bradley, 1973; Imaeda, 1985). Sequencing of the 16S rRNA gene has shown that there are no sequence differences between the members of the complex (Böddinghaus et al., 1990; Rogall et al., 1990). Furthermore, sequencing of the more variable internal transcribed spacers (ITSs) between 16S and 23S rRNA has also led to the same conclusion, proving the existence of a close evolutionary relationship (Frothingham et al., 1994; Glennon et al., 1994). DNA sequence analysis of $r p o B, k a t G, r p s L$ and gyr $A$ genes have revealed a very strong identity among bacteria of the $M$. tuberculosis complex (van Soolingen et al., 1997). The nucleotide sequence of the dnaJ gene is identical throughout the species of the $M$. tuberculosis complex (Takewaki et al., 1993); this is also true of the fragment of the $65 \mathrm{kDa}$ heat-shock protein used for PCR-restriction enzyme pattern analysis (Fiss et al., 1992; Plikaytis et al., 1992; Telenti et al., 1993). This $100 \%$ homology would support the theory that the $M$. tuberculosis complex represents a single species and there is a considerable debate concerning the classical classification. Several authors have stated that members of the complex should be grouped as varieties or subspecies of $M$. tuberculosis (Collins \& Yates, 1982) and that the division of the tuberculosis complex into five species is an artifact of the great historical interest in this pathogen (Frothingham et al., 1994). However, to our knowledge, the reclassification of these species as a single species has not been proposed formally. Their significance in human and veterinary medicine, and the differences in their epidemiology, pathology and antibiotic response mean that the former classification is a useful one.

These micro-organisms can be differentiated by means of phenetic characteristics, but, with numerical taxonomy, $M$. tuberculosis and $M$. bovis are connected to each other at the $97 \%$ level (Tsukamura, 1976). Identification of the $M$. tuberculosis complex has been traditionally based on growth characteristics (pigment production, colony morphology, growth rate) and biochemical tests. The most commonly used tests for speciation within the complex are niacin accumulation, nitratase activity, susceptibility to pyrazinamide and susceptibility to tiophene-2-carboxylic acid hydrazide (TCH). To complement the numerical studies, various genetic markers and molecular methods used in diagnosis and epidemiology have been used recently as taxonomic tools to classify different species of the $M$. tuberculosis complex (Sreevatsan et al., 1996; van Soolingen et al., 1997; Espinosa de los Monteros et al., 1998).

In this report we describe the results of a polyphasic taxonomy study of an unusual member of the $M$. tuberculosis complex, isolated from goats with disseminated lesions. These mycobacteria have clear phenetic, genetic and epidemiological traits that differentiate them from the classical species of this complex.

\section{METHODS}

Mycobacterial strains. A total of 121 isolates of mycobacteria were examined in this study. The isolates were obtained from tuberculosis-infected goats $(n=119)$, a sheep and a pig from herds located in several areas of Spain. Samples came from mediastinal, retropharyngeal and bronchial lymph nodes or from lungs with lesions. Strains and sources of mycobacteria are shown in Table 1.

Tissue samples were homogenized with sterile distilled water and decontaminated by the method of Tacquet \& Tison (1961) or with hexadecylpyridinium chloride (Corner \& Trajstman, 1988), centrifuged at 3500 r.p.m. (1068 $\mathrm{g}$ ) for $30 \mathrm{~min}$ (Sigma 3-10 centrifuge) and cultured on Coletsos (Coletsos, 1971) and $0.2 \%(\mathrm{w} / \mathrm{v})$ pyruvate-enriched Löwenstein-Jensen media (Anonymous, 1954) at $36^{\circ} \mathrm{C}$.

Phenetic characterization. The isolates were subcultured on Coletsos medium and incubated at $36{ }^{\circ} \mathrm{C}$ for 4 weeks. The recommended biochemical tests for determining the systematics of the genus Mycobacterium, described for new slowly-growing mycobacterial species (Lévy-Frébault \& Portaels, 1992), were applied.

Colonies were examined for acid-alcohol fastness by the Ziehl-Neelsen and auramine staining techniques. Type strain $\mathrm{gM}-1^{\mathrm{T}}$ (CIP $105776^{\mathrm{T}}$ ) was tested for growth rate, for the ability to grow at various temperatures $(25,30,36$ and $43^{\circ} \mathrm{C}$ ), for pigment production in the dark and photoactivity, for tolerance of sodium chloride, picric acid, hydroxylamine, $p$-nitrobenzoic acid and oleic acid, for nitrate reduction, urease production, catalase activity ( 22 and $68^{\circ} \mathrm{C}$ ), arylsulphatase activity, Tween 80 hydrolysis, thiophen-2-carboxylic acid hydrazide susceptibility (growth inhibition in $1,2,5$ and $10 \mu \mathrm{g} \mathrm{TCH} \mathrm{ml}{ }^{-1}$ incorporated into Middlebrook $7 \mathrm{H} 10$ ) and for pyrazinamidase production. These tests were performed according to standard procedures (Lutz, 1992). Niacin accumulation was determined according to the Konno method in Proskauer-Beck modified medium (Karlson et al., 1964). Other enzymic activities were determined using the API CORYNE and API ZYM systems (bioMérieux) after $24 \mathrm{~h}$ at $36^{\circ} \mathrm{C}$, testing in parallel clinical isolates of $M$. bovis and $M$. tuberculosis.

Susceptibility to first-line antituberculous drugs isoniazid $\left(0 \cdot 2\right.$ and $\left.1 \mu \mathrm{g} \mathrm{ml}^{-1}\right)$, rifampim $\left(1 \mu \mathrm{g} \mathrm{ml}^{-1}\right)$, ethambutol $(5$ and $\left.10 \mu \mathrm{g} \mathrm{ml}^{-1}\right)$, pyrazinamide $\left(50 \mu \mathrm{g} \mathrm{ml}^{-1}\right.$, at $\left.\mathrm{pH} 5 \cdot 5\right)$, streptomycin ( 2 and $\left.10 \mu \mathrm{g} \mathrm{ml}^{-1}\right), p$-aminosalicylic acid (2 and $\left.10 \mu \mathrm{g} \mathrm{ml}^{-1}\right)$, ofloxacin $\left(2.5 \mu \mathrm{g} \mathrm{ml}^{-1}\right)$, cycloserine $\left(30 \mu \mathrm{g} \mathrm{ml}^{-1}\right)$ and thiacetazone $\left(1 \mu \mathrm{g} \mathrm{ml^{-1 } )}\right.$ was determined using Middlebrook $7 \mathrm{H} 10$ medium according to standard procedures (Kent \& Kubica, 1985).

GLC. Mycobacterial lipids were extracted and derivatized to 
Table 1. Caprine mycobacterial strains used in this study

\begin{tabular}{|lll|}
\hline Geographic origin (Spain) & Herd and strain designation & Host species \\
\hline $\begin{array}{l}\text { Several villages of Catalunya } \\
\text { (north-east) }\end{array}$ & Herd c-1: gC-1 to gC-11 & Goat (38) and \\
& $\begin{array}{l}\text { Herd c-2: gC-12 to gC-26 } \\
\text { Herd c-3: gC-27 and gC-28 }\end{array}$ & \\
& Herd c-4: gC-29 to gC-31 & \\
& Herd c-5: gC-32 and gC-33 & \\
& Herd c-6: gC-34 to gC-38 & \\
& Herd o-1: oC-1 & Goat (33) \\
Madrid (central) & Herd c-7: gM-1 & \\
& Herd c-8: gM-2 to gM-33 & \\
Ávila and Valladolid & Herd c-9: gA-1 to gA-5 & Goat (47) \\
(entral west) & Herd c-10: gV-1 to gV-42 & \\
Badajoz (south-west) & Herd c-11: gB-1 and pB-1 & Goat (1) and pig (1) \\
\hline
\end{tabular}

* This strain was selected as the type strain (CIP 105776 ${ }^{\mathrm{T}}$ ).

methyl esters according to a recommended method (Luquin et al., 1991). Bacteria (10 mg wet weight) were suspended in $1 \mathrm{ml}$ of a mixture of methanol/toluene/sulphuric acid (30:15:1) and heated at $80^{\circ} \mathrm{C}$ overnight. After cooling at room temperature, the sample was extracted with $2 \mathrm{ml}$ hexane, transferred to a new tube and mixed with an equal volume of phosphate buffer $(0.3 \mathrm{M})$ and sodium hydroxide (pH 12). The hexane upper layer was selected, transferred to a new vial and evaporated under a stream of nitrogen gas. The methylated esters, secondary alcohols and mycolic acid cleavage products were analysed with a Hewlett Packard $5890 \mathrm{~A}$ gas chromatograph equipped with a flame-ionization detector. The identification of the eluted substances was performed by comparing the retention times with those of known standards on a fused silica capillary column $(15 \mathrm{~m}$ long $\times 0.25 \mathrm{~mm}$ i.d.) with cross-linked methyl silicone as the stationary phase (SPB-1, Supelco). The column was programmed from 175 to $300^{\circ} \mathrm{C}$, increasing at $8{ }^{\circ} \mathrm{C} \mathrm{min}^{-1}$ and was kept at $300^{\circ} \mathrm{C}$ for $15 \mathrm{~min}$. The temperatures for the injector and the detector were maintained at 275 and $315^{\circ} \mathrm{C}$, respectively. Helium was used as the carrier gas, with a flow rate of approximately $1 \mathrm{ml} \mathrm{min}$. The sample $(1 \mu \mathrm{l})$ was loaded with a split ratio of 1:50. The chromatogram was interpreted using a Hewlett Packard 3390A electronic integrator.

Molecular identification. From each isolate, a single colony was suspended in sterile distilled water, boiled for $10 \mathrm{~min}$ and stored frozen at $-20{ }^{\circ} \mathrm{C}$ until tested. The isolates were tested by PCR amplification of a genus-specific 16S rRNA fragment and MPB70 elements (Wilton \& Cousins, 1992), IS6110 (Hermans et al., 1990), IS1081 and mtp40 sequences (Liébana et al., 1996). Moreover, isolates were tested with the non-radioactive AccuProbe DNA probe (GenProbe) for the detection of $M$. tuberculosis complex according to the manufacturer's instructions.

The $5^{\prime} 1524 \mathrm{bp}$ region of the 16S rRNA gene of type strain $\left(\mathrm{gM}-\mathrm{l}^{\mathrm{T}}\right)$ was amplified by PCR with universal primer 246 (positions 8-28; Escherichia coli numbering) (5' AGA GTT TGA TCC TGG CTC AG $3^{\prime}$ ) and reverse pH (positions 1540-1521) (5’ AAG GAG GTG ATC CAG CCG CA 3').
The amplified 16S rRNA fragment was sequenced using primers aimed at the conserved regions of the rRNA.

Detection of gene polymorphisms. One isolate from each herd was tested with the allele-specific PCR for $p n c A$ that differentiates the nucleotide at position 169 (Espinosa de los Monteros et al., 1998). Briefly, each sample was subjected to two differential amplifications; both reactions were performed with the same forward primer, pncATB $1.2\left(5^{\prime}\right.$-ATG CGG GCG TTG ATC ATC GTC-3'), and one of the two discriminator reverse primers, i.e. pncAMT-2 (5'-CGG TGT GCC GGA GAA GCG G-3') or pncAMB-2 (5'-CGG TGT GCC GGA GAA GCC G-3'), according to the methods of Espinosa de los Monteros et al. (1998).

Several complete genes (or parts containing the expected polymorphism) of the type strain were characterized by DNA sequencing. The complete pyrazinamidase ( $p n c A)$ gene was amplified with primers pncATB-1 (5'-AAA GAA TTC ATG CGG GCG TTG ATC ATC GT-3') and pncATB-2 (5'-AAA GAA TTC TCA GGA GCT GCA AAC CAA CTC-3') based on the sequence described (Scorpio \& Zhang, 1996). The amplified product is a DNA fragment of $574 \mathrm{bp}$. A $620 \mathrm{bp}$ portion of the catalase-peroxidase $(\mathrm{kat} G)$ gene was amplified with forward primer katG904 (5'-AGC TCG TAT GGC ACC GGA AC-3') and reverse primer katG1523 (5'TTG ACC TCC CAC CCG ACT TG-3') (Uhl et al., 1996). A $548 \mathrm{bp}$ fragment of the $\operatorname{oxy} R$ homologue gene was amplified with forward primer (5'-GGT GAT ATA TCA CAC CAT A-3') and reverse primer (5'-CTA TGC GAT CAG GCG TAC TTG-3') (Sreevatsan et al., 1996). A 320 bp (78 to 397) fragment of the gene gyr $A$ that encodes the subunit A of the DNA gyrase was amplified with primers gyrAl (5'-CAG CTA CAT CGA CTA TGC G-3') and gyrA2 (5'-GGG CTT CGG TGT ACC TCA T-3') (Takiff $e t$ al., 1994).

Sequencing was performed with the DyeDeoxy (dRhodamine) Terminator Cycle Sequencing kit (Applied Biosystems) in an automatic ABI Prism 373 DNA sequencer with software provided by the manufacturer (Applied Biosystems) (C.I.B. and C.N.B. Sequencing Facilities, 
Table 2. Source of the spoligotyping patterns of the $M$. tuberculosis complex strains included in the dendrogram (Fig. 1)

Data were compiled from published references and/or obtained in our laboratories.

\begin{tabular}{|c|c|c|c|c|}
\hline $\begin{array}{l}\text { No. in } \\
\text { Fig. } 1\end{array}$ & Species/strain & Source & Country & Reference \\
\hline & \multicolumn{4}{|c|}{ M. tuberculosis subsp. caprae } \\
\hline 1 & spc-1 $\left(\mathrm{gM}-1^{\mathrm{T}}\right)$ & Goat, sheep & Spain & Aranaz et al. (1996a)/* \\
\hline 2 & $\mathrm{spc}-2(\mathrm{gC}-31)$ & Goat & Spain & Aranaz et al. $(1996 \mathrm{a}) /^{*}$ \\
\hline 3 & $\mathrm{spc}-3(\mathrm{gV}-1)$ & Goat & Spain & Aranaz et al. $(1996 \mathrm{a}) /^{*}$ \\
\hline 4 & $\begin{array}{l}\text { spc- } 4(\mathrm{gC}-11) \\
\text { M. bovis }\end{array}$ & Goat & Spain & Aranaz et al. $(1996 \mathrm{a}) / *$ \\
\hline 5 & spb-1 & Cattle & Spain & Aranaz et al. (1996a)/* \\
\hline 6 & $\mathrm{spb}-3$ & Cattle & Spain & Aranaz et al. $(1996 \mathrm{a}) /^{*}$ \\
\hline 7 & spb-6 & Cattle, wild boar & Spain & Aranaz et al. $(1996 \mathrm{a}) /^{*}$ \\
\hline 8 & spb-7 & Cattle, wild boar & Spain & Aranaz et al. (1996a)/* \\
\hline 9 & spb- 8 & Cattle & Spain & Aranaz et al. (1996a)/* \\
\hline 10 & spb-13 & Cattle & Spain & Aranaz et al. $(1996 \mathrm{a}) /^{*}$ \\
\hline 11 & spb-15 & Cattle, deer & Spain & Aranaz et al. $(1996 a) /^{*}$ \\
\hline 12 & MDR outbreak $\dagger$ & HIV-infected human beings & Spain & Blázquez et al (1997) \\
\hline 13 & sp-1 & Cattle, buffalo, deer, goat, pig, badger & Australia, Ireland, Iran & Cousins et al. (1998) \\
\hline 14 & sp-6 & Human beings & Ireland & Cousins et al. (1998) \\
\hline 15 & $\mathrm{sp}-7$ & Human beings & Iran & Cousins et al. (1998) \\
\hline 16 & sp-8 & Buffalo & Australia & Cousins et al. (1998) \\
\hline 17 & sp-37 & Cattle & $\mathrm{UK}$ & Cousins et al. (1998) \\
\hline 18 & sp-42 & AN5 reference strain, veal & - & Cousins et al. (1998) \\
\hline 19 & sp-43 & Human beings, cattle, elk, bison & Iran, Canada & Cousins et al. (1998) \\
\hline 20 & sp-44 & Eland & Canada & Cousins et al. (1998) \\
\hline 21 & $\mathrm{sp}-46$ & Cattle & Iran & Cousins et al. (1998) \\
\hline 22 & $\begin{array}{l}\text { sp-47 } \\
\text { BCG }\end{array}$ & Cattle, elk, deer, cougar & Canada & Cousins et al. (1998) \\
\hline 23 & Pasteur & Vaccine strain & - & Goguet et al. (1997)/* \\
\hline 24 & Russian & Vaccine strain & - & Goguet et al. $(1997) / *$ \\
\hline 25 & $\begin{array}{l}\text { Japanese } \\
\text { M. tuberculosis }\end{array}$ & Vaccine strain & - & Goguet et al. (1997)/* \\
\hline 26 & H37Rv & Reference strain & - & All references $/^{*}$ \\
\hline 27 & Outbreak A & Human beings & France & Goguet et al. (1997) \\
\hline 28 & Outbreak B & Human beings & France & Goguet et al. (1997) \\
\hline 29 & Patient 1 & Human being & France & Goguet et al. (1997) \\
\hline 30 & Patient 2 & Human being & France & Goguet et al. (1997) \\
\hline 31 & E-1 & Elephant & Spain & * \\
\hline 32 & Dog 1 & Pet dog & Spain & $*$ \\
\hline 33 & Dog 2 & Pet dog & Spain & $*$ \\
\hline 34 & RyC 1 & Human being & Spain & $*$ \\
\hline 35 & RyC 2 & Human being & Spain & $*$ \\
\hline 36 & Cluster A & Human beings & $\begin{array}{l}\text { Guadeloupe, French } \\
\text { West Indies }\end{array}$ & Sola et al. (1998) \\
\hline 37 & Cluster C & Human beings & $\begin{array}{l}\text { Guadeloupe, French } \\
\text { West Indies }\end{array}$ & Sola et al. (1998) \\
\hline 38 & Cluster 1 & Human beings & The Netherlands & Kamerbeek et al. (1997) \\
\hline 39 & $\begin{array}{l}\text { Cluster } 2 \\
\text { M. africanum }\end{array}$ & Human beings & The Netherlands & Kamerbeek et al. (1997) \\
\hline 40 & TMC 12 & Reference strain, human being & - & * \\
\hline 41 & TMC 3 & Reference strain, human being & - & * \\
\hline 42 & TMC 54 & Reference strain, human being & - & * \\
\hline 43 & $\begin{array}{l}\text { Clinical isolate } \\
\text { M. microti }\end{array}$ & Human being & Spain & * \\
\hline 44 & NCTC $08710^{\mathrm{T}}$ & Reference strain, vole & - & * \\
\hline 45 & $\mathrm{RyC} \mathrm{m}$ & Laboratory isolate & Spain & * \\
\hline
\end{tabular}

* Obtained in our laboratories.

$\dagger$ MDR, Multidrug-resistant. 
Madrid). The sequences generated were aligned with published mycobacterial sequences from the GenBank databases (accession nos U59967, Scorpio \& Zhang, 1996; X83277, Heym et al., 1995; U18263, Sherman et al., 1995; and L27512, Takiff et al., 1994).

Genetic fingerprinting analysis. Procedures for the direct variable repeat (DVR) spacer oligonucleotide typing (DVRspoligotyping) (Kamerbeek et al., 1997) and RFLP associated with the IS6110 element, direct repeat (DR) and polymorphic $\mathrm{G}+\mathrm{C}$-rich sequences (PGRS) have been previously described (Aranaz et al., 1996a, 1998; Liébana et al., 1997). Briefly, isolates were grown in OADC (oleic acid, albumin, dextrose and catalase)-enriched Middlebrook 7H9 (Difco), and chromosomal DNA was extracted as previously described (Cousins et al., 1993). DNA was digested with restriction endonucleases $P v u \mathrm{II}$ and AluI (Boehringer Mannheim), Southern-blotted and hybridized with the strain-specific markers. The probe for the IS6110 right-hand side of the PvuII site was a $245 \mathrm{bp}$ fragment amplified by PCR with primers INS-1 and INS-2 (Hermans et al., 1990) and labelled with digoxigenin-11-dUTP using the DIG High Prime kit (Boehringer Mannheim). Oligonucleotide probes IS6110 (left-hand side: 5'-CGA TGA ACC GCC CCG GCA TGT CCG GAG ACT C-3'), DR (5'-GTG GTC AGA CCC AAA ACC CCG AGA GGG GAC GGA AAC-3') and PGRS (5'-CCG CCG TTG CCG CCG TTG CCG CCG TTG CCG CCG-3') were end-labelled with digoxigenin-11-dUTP using the DIG oligonucleotide tailing kit (Boehringer Mannheim). The hybridized probes were detected using the alkaline-phosphatase-conjugated antibody detection kit and chemiluminescent substrate for alkaline phosphatase (CSPD; Boehringer Mannheim).

Spoligotyping (Kamerbeek et al., 1997) was used to determine the presence or absence of spacer DNA sequences in the DR locus. Spacers were amplified by PCR with primers Dr-a and Dr-b (biotin-labelled) and subsequently detected by hybridization on to a membrane containing 37 oligonucleotides derived from $M$. tuberculosis and six from $M$. bovis BCG covalently linked. Labelled hybridized product was detected with streptavidin-peroxidase conjugate (Boehringer Mannheim) and the ECL system (Amersham). The analysis of the hybridization pattern was performed with the GELCOMPAR program, version 3.1 (Applied Maths). The patterns obtained were compared with a large database containing approximately $500 \mathrm{M}$. bovis strains from cattle, pets and wild animals (wild boar, red deer and fallow deer) from several Spanish regions; the database included strains isolated from humans.

The caprine isolates were included in a dendrogram generated with spoligotyping patterns of a representative number of strains of the classical species belonging to the $M$. tuberculosis complex that have been obtained at our laboratories or published in the literature (Table 2). The bands obtained in the spoligotyping were treated as discrete characters and recorded in a data matrix by scoring 1 for the presence and 0 for the absence of every spacer. Similarity between strains was determined with the software TAXAN 3.0 (Sea Grant College) using the band-sharing coefficient calculated by the formula of Jaccard $\left(N_{\mathrm{xy}} /\left(N_{\mathrm{x}}+N_{\mathrm{y}}-N_{\mathrm{xy}}\right)\right.$ where $N_{\mathrm{xy}}$ is the number of spacers common to strains x and $\mathrm{y}$, and $N_{\mathrm{x}}$ and $N_{\mathrm{y}}$ are the number of spacers in strain x and y, respectively).

\section{RESULTS}

\section{Morphology and growth}

The organism was an acid-alcohol-fast, non-motile rod that grew slowly at $36^{\circ} \mathrm{C}$, forming smooth and non-chromogenic colonies. Visible growth in primary culture usually took 4-6 weeks incubation. Subculture growth was achieved in 3-4 weeks at $36^{\circ} \mathrm{C}$, but not after 8 weeks at 25,30 or $43^{\circ} \mathrm{C}$. Colonies appeared faster and in greater numbers in Coletsos and Löwenstein-Jensen media with pyruvate $(20 \mathrm{~d})$ than in conventional Löwenstein-Jensen (26 d). The organisms gave a cording pattern in Proskauer medium, though poorly in comparison with $M$. tuberculosis.

\section{Phenotypic characteristics}

Growth on Middlebrook 7H10 medium in the presence of sodium chloride $(5 \% \mathrm{w} / \mathrm{v})$, picric acid $(0 \cdot 2 \%)$, hydroxylamine $\left(500 \mu \mathrm{g} \mathrm{ml} \mathrm{m}^{-1}\right), p$-nitrobenzoic acid $\left(500 \mu \mathrm{g} \mathrm{ml}^{-1}\right)$ or oleic acid $\left(250 \mu \mathrm{g} \mathrm{ml}^{-1}\right)$ was negative. The isolates were negative for nitrate reductase and niacin accumulation. Pyrazinamidase activity was not detected on Middlebrook 7H10 medium (4 and $14 \mathrm{~d}$ ). They were PZA $\left(50 \mu \mathrm{g} \mathrm{ml}^{-1}\right)$-sensitive and resistant to 1 or $2 \mu \mathrm{g} \mathrm{TCH} \mathrm{ml}^{-1}$ (5 and 2-5\% colonies, respectively) but not to 5 or $10 \mu \mathrm{g} \mathrm{TCH} \mathrm{ml} \mathrm{m}^{-1}$. They weakly hydrolysed Tween 80 (after $10 \mathrm{~d}$ ) and did not hydrolyse arylsulphatase (after 3 and $14 \mathrm{~d}$ ). The catalase test was positive at room temperature and negative at $68^{\circ} \mathrm{C}$. Urease activity (Christensen) was negative and urease activity (discs) was positive after $4 \mathrm{~h}$. Acid phosphatase, alkaline phosphatase, $\beta$-glucosidase and esterase were positive as detected with the API CORYNE and API ZYM systems. The type strain was susceptible to all antibiotics tested $[1 \%$ of colonies were resistant to pyrazinamide (PZA)].

\section{GLC}

The pattern obtained and the percentage of the constituents were characteristic of micro-organisms of the $M$. tuberculosis complex : there were large amounts of hexadecanoic $\left(\mathrm{C}_{16: 0}\right)$, octadecanoic $\left(\mathrm{C}_{18: 0}\right)$ and octadecenoic $\left(\mathrm{C}_{18: 1}\right)$ acids, as well as tuberculostearic (10-methyloctadecanoic) acid. Hexacosanoic acid $\left(\mathrm{C}_{26: 0}\right)$ was the primary mycolic acid cleavage product of the strain; secondary alcohols were not observed.

\section{Molecular identification}

A DNA fragment of $1030 \mathrm{bp}$ was obtained in all isolates after PCR amplification of a 16S rRNA genus Mycobacterium-specific region. All isolates harboured the sequences IS6110, IS1081 and MPB70 reported to 
Table 3. Differential characteristics of the caprine mycobacterial isolate in comparison with other members of the $M$. tuberculosis complex

Data were taken from references cited in the text. Abbreviations: +, positive; - , negative; v, variable; S, sensitive; R, resistant.

\begin{tabular}{|c|c|c|c|c|c|c|c|c|c|c|c|c|}
\hline Species & IS6110 & IS1081 & MPB70 & mtp40 & $\begin{array}{c}\text { Niacin } \\
\text { accumulation }\end{array}$ & $\begin{array}{l}\text { Nitrate } \\
\text { reduction }\end{array}$ & TCH & PZA & $\begin{array}{c}p n c A \\
\text { c } 57\end{array}$ & $\begin{array}{l}\text { katG } \\
\text { c } 463\end{array}$ & $\begin{array}{l}\text { oxyR } \\
\text { n } 285\end{array}$ & $\begin{array}{r}g y r A \\
\text { c } 95\end{array}$ \\
\hline \multicolumn{13}{|l|}{ M. tuberculosis } \\
\hline Classical & $+^{*}$ & + & + & $+^{*}$ & + & + & $\mathrm{R}$ & $\mathrm{S}$ & $\mathrm{CAC}$ (His) & $\begin{array}{l}\text { CGG (Arg), } \\
\text { CTG (Leu) }\end{array}$ & G & $\begin{array}{l}\text { AGC (Ser), } \\
\text { ACC (Thr) }\end{array}$ \\
\hline Asian & $+^{*}$ & + & + & + & + & + & $\mathrm{S}$ & S & $\mathrm{CAC}$ & CGG/CTG & G & - \\
\hline \multicolumn{13}{|l|}{ M. africanum } \\
\hline Type I & + & + & + & $+^{*}$ & $\mathrm{v}$ & - & $\mathrm{S}$ & $\mathrm{S}$ & $\mathrm{CAC}$ & CTG & $\mathrm{G}$ & $\mathrm{ACC}$ \\
\hline Type II & + & + & + & $t^{*}$ & $\mathrm{v}$ & + & $\mathrm{S}$ & $\mathrm{S}$ & $\mathrm{CAC}$ & CTG & $\mathrm{G}$ & $\mathrm{ACC}$ \\
\hline M. bovis & + & + & + & - & - & - & $\mathrm{S}$ & $\mathrm{R}$ & GAC (Asp) & CTG & A & $\mathrm{ACC}$ \\
\hline M. bovis $\mathrm{BCG}$ & + & + & + & - & - & - & $\mathrm{S}$ & $\mathrm{R}$ & GAC & CTG & A & $\mathrm{ACC}$ \\
\hline M. microti & + & + & + & - & + & - & $S$ & $S$ & $\mathrm{CAC}$ & CTG & $\mathrm{G}$ & $\mathrm{ACC}$ \\
\hline M. caprae & + & + & + & - & - & - & $\mathbf{S} \dagger$ & $\mathbf{S}$ & CAC & CTG & $\mathbf{A}$ & $\mathrm{ACC}$ \\
\hline
\end{tabular}

* Very occasionally, members of these species lack the genetic element (Liébana et al., 1996).

$\uparrow$ Resistant to 1 and $2 \mu \mathrm{g} \mathrm{TCH} \mathrm{ml} l^{-1}$, but sensitive to 5 and $10 \mu \mathrm{g} \mathrm{TCH} \mathrm{ml}{ }^{-1}$.

be specific for micro-organisms within the $M$. $t u$ berculosis complex, but all of them lacked the mtp40 element (as demonstrated by PCR amplification). The AccuProbe (GenProbe) system also classified these isolates within the $M$. tuberculosis complex.

The $5^{\prime} 1524 \mathrm{bp}$ of the 16S rRNA sequence of the type strain was determined (EMBL accession no. AJ131120) and was identical to published 16S rRNA gene sequences of $M$. tuberculosis complex strains.

\section{Gene polymorphisms}

All isolates tested with the allele-specific PCR presented a pnc $A$ polymorphism (Scorpio et al., 1997), characteristic of $M$. tuberculosis, considered as the wild-type sequence. This sequence should code for a functional enzyme. However, $M$. bovis and BCG have a single point mutation in the pnc $A$ gene, changing a $\mathrm{C}$ to a $\mathrm{G}$ at nucleotide position 169 , resulting in a His to Asp substitution (Scorpio \& Zhang, 1996). DNA sequencing of the complete pncA gene of the caprine type strain did not detect other mutations.

The katG sequence of the caprine isolate contains a thymine instead of a guanine at position 1388 , thus codon 463 (CTG) gives a Leu. This polymorphism is found in $M$. bovis, $M$. africanum, $M$. microti and in some M. tuberculosis strains (Muser et al., 1996; Sreevatsan et al., 1997). The oxyR analysis showed that the mycobacterial isolates from goats had an adenine at position 285 . This polymorphism differentiates $M$. bovis from other complex members that have a $\mathrm{G}$ residue (Sreevatsan et al., 1996). Codon 95 of the gyr A gene in the goat isolate displayed an ACC (threonine), a fluoroquinolone-susceptible pattern found in some $M$. tuberculosis strains and in M. bovis, BCG and $M$. africanum (Takiff et al., 1994). No additional sequence variations were found. Table 3 shows the results of the most representative tests cited above.

\section{RFLP and spoligotyping analysis}

After characterization by IS6110, DR and PGRSassociated RFLPs and DVR-spoligotyping, the fingerprinting patterns of the caprine strains formed a tight homogeneous group. When the caprine patterns were analysed in the context of results obtained with a wide group of $M$. bovis strains obtained from cattle, deer, wild boar and cats typed with the same genetic elements, the caprine group was clearly segregated by means of both DVR-spoligotyping and RFLPs (Aranaz et al., 1998). The isolate obtained from the pig from herd c-11 had the same characteristics as the caprine mycobacterial isolates.

The dendrogram (Fig. 1) shows the relationships of the spoligotyping patterns of $M$. tuberculosis complex organisms. A major division, separated at a distance of $0 \cdot 2$, includes the $M$. microti reference strain NCTC $08710^{\mathrm{T}}$ and a laboratory isolate. The broad group of strains is divided into two major clusters at a distance of $0 \cdot 35$. The first cluster comprises only the caprine mycobacterial isolates. The second cluster is subsequently divided at 0.58 into two branches: one of them includes strains of $M$. bovis and $M$. africanum; the second one includes the $M$. tuberculosis strains. 
Similarity

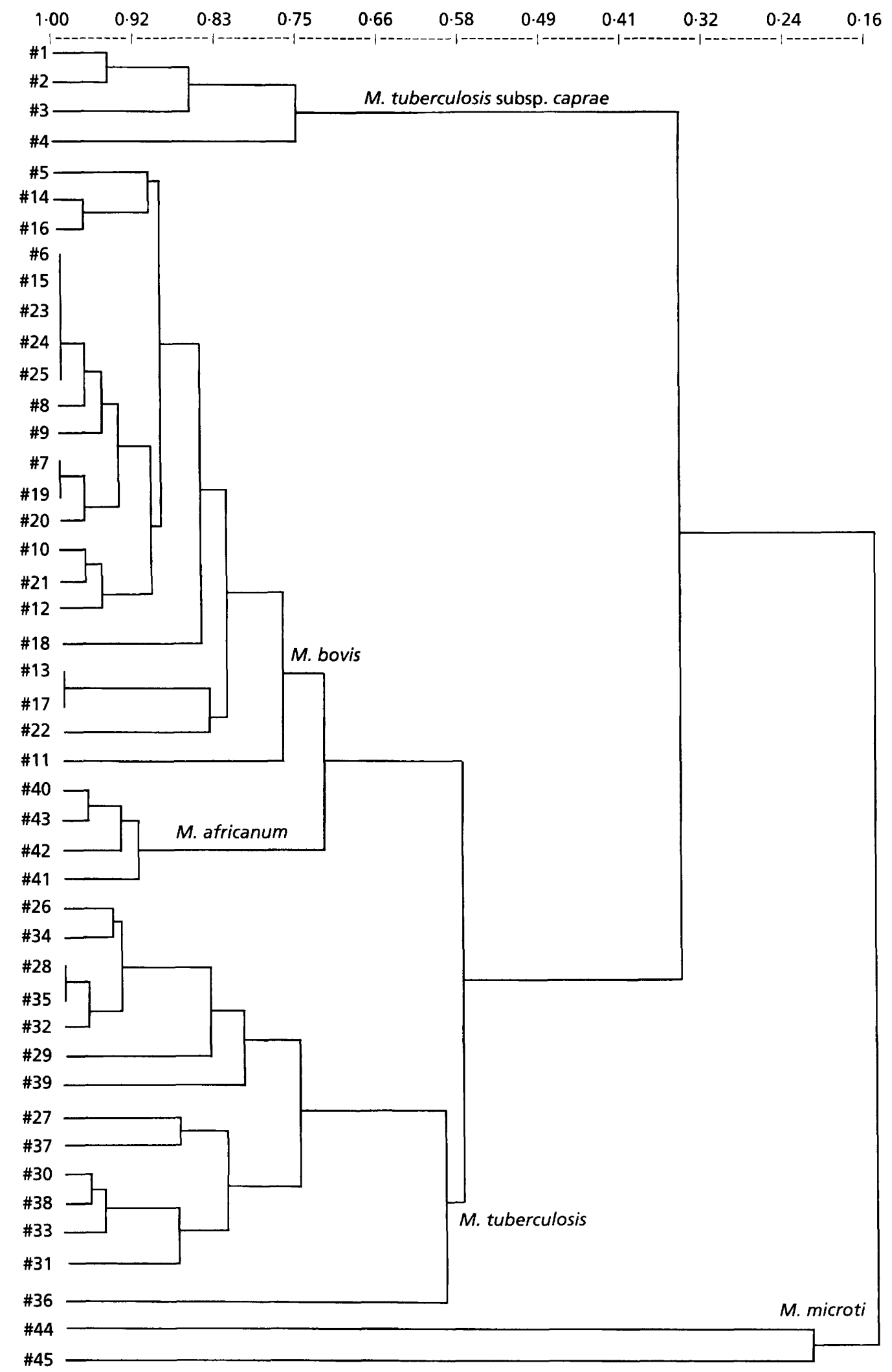

Fig. 1. Dendrogram constructed with the spoligotyping patterns of 45 Mycobacterium tuberculosis complex organisms, including representive reference strains and clinical isolates of all species (data in Table 2). Pattern similarities were analysed with the TAXAN software; the JACCARD algorithm was used for analysis. 


\section{DISCUSSION}

In this report we describe the results of a polyphasic taxonomy study of an unusual mycobacterium that belongs to the $M$. tuberculosis complex. The isolates share the presence of DNA elements, such as IS6110, IS1081, MPB70 and DR, that are considered specific to the $M$. tuberculosis complex. The AccuProbe test, 16S rRNA gene sequencing and GLC confirm these results. The results of these tests, coupled with the animal origin of the isolates, initially led us to identify this group of strains as $M$. bovis. However, further study highlighted the presence of the special phenetic and genetic characteristics that indicated that these strains differed from the other members of the complex.

Firstly, the isolates were PZA sensitive, whereas $M$. bovis isolates are naturally resistant to PZA. Pyrazinamidase activity is a stable feature commonly used to distinguish $M$. bovis from the other members of the $M$. tuberculosis complex. The caprine isolates tested had the wild-type polymorphism found in $M$. tuberculosis, M. microti and M. africanum (Scorpio et al., 1997; Sreevatsan et al., 1997). These results agree with those published by Espinosa de los Monteros et $a l$. (1998). No other mutations were found in the pnc $A$ gene sequence. Other enzymic activities that distinguish between the caprine isolates and the classical $M$. bovis are alkaline phosphatase, $\beta$-glucosidase and hydrolysis of Tween 80 . Furthermore, the caprine isolates can be distinguished from $M$. africanum and $M$. microti by TCH susceptibility. Secondly, the special combination of the polymorphisms in the sequenced genes has not been found in the other members of the complex and could be considered ancestral in mycobacteria. We speculate, therefore, that goat isolates could be the ancestral condition suggested by Sreevatsan et al. (1997) and Espinosa de los Monteros et al. (1998). Thirdly, the fingerprinting patterns obtained with IS6110, DR and PGRS-associated RFLP and DVR-spoligotyping are very different from those obtained for other members of the complex examined in our laboratory or published by other authors (Aranaz et al., 1996a, 1998; Blázquez et al., 1997; Goguet et al., 1997; Kamerbeek et al., 1997; Cousins et al., 1998; Sola et al., 1998). All of the goat isolates tested were included in a common cluster of patterns for both RFLP and DVR-spoligotyping, and were clearly segregated from the bovine and wildanimal isolates. van Soolingen et al. (1997) reported the usefulness of large DNA fingerprint databases (such as those of IS6110 and spoligotypes) in mycobacterial systematics. These results show that caprine strains are a genetically distinct cluster within the $M$. tuberculosis complex.

The great importance of $M$. tuberculosis as a pathogen of humans and animals has led workers to allot separate species names to variants that, when examined by criteria applied to other species, could be recognizable as intraspecific variants of a single species
(Collins \& Yates, 1982). As an example, the 16S rRNA gene sequence, considered specific to nearly every organism and used to establish phylogenetic relationships and identify micro-organisms (Stackebrandt \& Woese, 1981), is the same in all members of the $M$. tuberculosis complex. However, this apparent lack of correlation between 16S rDNA sequences and species assignment also occurs with other species of the genus Mycobacterium, i.e. between Mycobacterium malmoense and Mycobacterium szulgai, or Mycobacterium gastri and Mycobacterium kansasii (Rogall et al., 1990). The existence of a spectrum of variants could confirm the theory that we are looking at a single species (M. tuberculosis) with different variants owing to selection by the environment and host niches, thus suggesting a certain degree of host specificity. As a consequence of the existing controversy in the classification of the species within the $M$. tuberculosis complex, the biological meaning of such variations is unclear.

It is worth noting that the caprine strains were isolated from different geographical areas of Spain, and that in most cases the same typing pattern was found in all tuberculous goats of a herd. These points highlight the ecological and clinical relevance of this taxon. On the other hand, only a few cases of tuberculosis have been reported in goats in countries with a high incidence of $M$. bovis in cattle. We suggest the posssibility that this unusual strain is a variety more adapted to goats than is $M$. bovis, but this theory must be confirmed by experimental infections. It is tempting to speculate as to how long tuberculosis may have been endemic in goats and whether the close relationship between goats and this mycobacterial isolate is responsible for such limited genetic diversity.

As with the other members of the complex, a degree of host specificity does not preclude the possibility of infection of other species. In this study, the caprine mycobacterial isolate was also found in a sheep and in a pig, both of which were in close contact with goats. Surprisingly, despite the high incidence of tuberculosis in Spanish goat herds, the caprine type has not been found in cattle. While this work was in progress, Gutiérrez et al. (1997) reported three human isolates that displayed caprine spoligotyping patterns. When the origin of the strains was traced, it was found that one of the patients was resident in a rural area in which goat farming was common; the second patient worked in an abattoir and the third was a veterinary practitioner (Gutiérrez et al., 1997). The public-health implications of these strains deserve further investigation.

The biochemical, genetic and epidemiological differences found between the classical members of the $M$. tuberculosis complex and the mycobacteria isolated from the goat herds suggest that the caprine isolates could be considered as belonging to a new member of the $M$. tuberculosis complex. These strains could be clasified as a new taxon in its own right, rather than a 
sub-group of $M$. bovis. We propose the name Mycobacterium tuberculosis subsp. caprae for these strains.

\section{Description of Mycobacterium tuberculosis subsp. caprae sp. nov.}

Mycobacterium tuberculosis subsp. caprae (ca'p.rae. L. fem. gen. n. caprae referring to capra, the L. fem. n. for goat, the host animal from which the bacteria are isolated).

Strains can be isolated from the lymph nodes and lungs of tuberculous goats. These organisms are acidalcohol-fast, non-spore forming, non-motile bacilli with weak cording formation. Growth is enhanced with pyruvate and usually occurs after 4-6 weeks incubation at $36^{\circ} \mathrm{C}$. Colonies are smooth and nonchromogenic. Strains are negative for niacin accumulation and nitrate reduction, sensitive to PZA (50 $\mu \mathrm{g}$ $\mathrm{ml}^{-1}$ ), resistant to 1 and $2 \mu \mathrm{g} \mathrm{TCH} \mathrm{ml} \mathrm{T}^{-1}$, but sensitive to 5 and $10 \mu \mathrm{g} \mathrm{TCH} \mathrm{ml} l^{-1}$. They weakly hydrolyse Tween $80(10 \mathrm{~d})$ and do not hydrolyse arylsulphatase ( 3 and $14 \mathrm{~d}$ ). Other enzymic activities include acid and alkaline phosphatases and $\beta$-glucosidase. Catalase test is positive at room temperature and negative at $68{ }^{\circ} \mathrm{C}$. The key biochemical features that separate this subspecies from the previously established taxa within the $M$. tuberculosis complex are as follows: niacin accumulation, nitrate reduction and $\mathrm{TCH}$ susceptibility differentiate the new taxon from $M$. tuberculosis; PZA susceptibility differentiates it from $M$. bovis and $M$. bovis $\mathrm{BCG}$; resistance to $1 \mu \mathrm{g} \mathrm{TCH} \mathrm{ml}{ }^{-1}$ differentiates it from $M$. africanum; and niacin accumulation differentiates it from $M$. microti. The sequence of the $16 \mathrm{~S}$ rRNA and the GLC profile are characteristic of all members of the $M$. tuberculosis complex. All isolates contain the sequences IS6110, IS1081 and MPB70 and lack the $m t p 40$ element. The strains present a special combination of gene polymorphisms: the pncA gene contains CAC (His) at codon 57; codon 463 of the kat $G$ gene, CTG, gives a Leu; nucleotide 285 of the oxy $R$ pseudogene is an adenine; and codon 95 of the gyrA gene displays an ACC (Thr). The DVRspoligotyping and RFLP patterns are unique. The type strain is $\mathrm{gM}-1^{\mathrm{T}}\left(=\mathrm{CIP} 105776^{\mathrm{T}}\right)$, which has the characteristics described for the taxon.

\section{ACKNOWLEDGEMENTS}

This work received financial support from the projects I+D 0030/94 and Coor 25/96 (Comunidad Autónoma de Madrid), and FIS 98/9060. We thank Felipe Vilas (Salud Pública, CAM) for his encouragement; J. J. Urquía (Consejería de Economía, CAM), C. Novoa, X. Pickering, B. Sánchez and P. García (Patología Animal II, UCM), M. Domingo and D. Vidal (Anatomía Patológica, UAB) and F. J. Reviriego and J. Cermeño (Sanidad Animal, Ávila) for providing the goat tissue samples; and J. Hermoso and A. Tato (Patología Infecciosa, UEX) for the isolates from Badajoz. We are grateful to S. Neill (DANI, Belfast) for careful revision of the manuscript.

\section{REFERENCES}

Alfredsen, S. \& Saxegaard, F. (1992). An outbreak of tuberculosis in pigs and cattle caused by Mycobacterium africanum. Vet Rec 131, 51-53.

Anonymous (1954). Towards a standardization of laboratory methods. Bull Int Union Tuberc 25, 89-95.

Aranaz, A., Liébana, E., Mateos, A. \& 8 other authors (1996a). Spacer oligonucleotide typing of Mycobacterium bovis strains from cattle and other animals: a tool for studying the epidemiology of tuberculosis. J Clin Microbiol 34, 2734-2740.

Aranaz, A., Liébana, E., Pickering, X., Novoa, C., Mateos, A. \& Domínguez, L. (1996b). Use of polymerase chain reaction in the diagnosis of tuberculosis in cats and dogs. Vet Rec 138, 276-280.

Aranaz, A., Liébana, E., Mateos, A., Domínguez, L. \& Cousins, D. V. (1998). Restriction fragment length polymorphism and spacer oligonucleotide typing: a comparative analysis of fingerprinting strategies for Mycobacterium bovis. Vet Microbiol 61, 311-324.

Baess, I. (1979). Deoxyribonucleic acid relatedness among species of slowly-growing mycobacteria. Acta Pathol Microbiol Scand Sect B 87, 221-226.

Blázquez, J., Espinosa de los Monteros, L. E., Samper, S., Martín, C., Guerrero, A., Cobo, J., van Embden, J., Baquero, F. \& GómezMampaso, E. (1997). Genetic characterization of multidrugresistant Mycobacterium bovis strains from a hospital outbreak involving human immunodeficiency virus-positive patients. $J$ Clin Microbiol 35, 1390-1393.

Böddinghaus, B., Rogall, T., Floht, T., Blöcker, H. \& Böttger, E. C. (1990). Detection and identification of mycobacteria by amplification of rRNA. J Clin Microbiol 28, 1751-1759.

Bradley, S. G. (1973). Relationships among mycobacteria and nocardiae based upon deoxyribonucleic acid reassociation. $J$ Bacteriol 113, 645-651.

Castets, M., Rist, N. \& Boisvert, H. (1969). La varieté africaine du bacille tuberculeux humain. Méd Afr Noire 16, 321-322.

Clercx, C., Coignoul, F., Jakovljevic, S., Balligand, M., Mainil, J., Henroteaux, M. \& Kaeckenbeeck, A. (1992). Tuberculosis in dogs: a case report and review of the literature. J Am Anim Hosp Assoc 28, 207-211.

Coletsos, P. J. (1971). Isolation des mycobactéries. Rev Tuberc Pneumol (Paris) 35, 601-616.

Collins, C. H. \& Yates, M. D. (1982). Subdivision of Mycobacterium tuberculosis into five variants for epidemiological purposes: methods and nomenclature. $J$ Hyg 89, 235-242.

Collins, C. H. \& Grange, J. M. (1983). The bovine tubercle bacillus. $J$ Appl Bacteriol 55, 13-29.

Corner, L. A. \& Trajstman, A. C. (1988). An evaluation of 1hexadecyl-pyridinium chloride as a decontaminant in the primary isolation of Mycobacterium bovis from bovine lesions. Vet Microbiol 18, 127-134.

Cousins, D. V., Williams, S. W., Ross, B. C. \& Ellis, T. M. (1993). Use of a repetitive element isolated from Mycobacterium tuberculosis in hybridisation studies with Mycobacterium bovis: a new tool for epidemiological studies of bovine tuberculosis. Vet Microbiol 37, 1-17.

Cousins D., Williams, S., Liébana, E., Aranaz, A., Bunschoten, A., van Embden, J. \& Ellis, T. (1998). Evaluation of four DNA typing techniques in epidemiological investigations of bovine tuberculosis. J Clin Microbiol 36, 168-178.

Espinosa de los Monteros, L. E., Galán, J. C., Gutiérrez, M. \& 8 other authors (1998). Allele-specific method based on pnc $A$ and 
oxy $R$ sequences for distinguishing Mycobacterum bovis from Mycobacterium tuberculosis: intraspecific $M$. bovis pncA sequence polymorphism. J Clin Microbiol 36, 239-242.

Fiss, E. H., Chehab, F. F. \& Brooks, G. F. (1992). DNA amplification and reverse dot blot hybridization for detection and identification of mycobacteria to the species level in the clinical laboratory. J Clin Microbiol 30, 1220-1224.

Frothingham, R., Hills, H. G. \& Wilson, K. H. (1994). Extensive DNA sequence conservation throughout the Mycobacterium tuberculosis complex. J Clin Microbiol 32, 1639-1643.

Glennon, M., Smith, T., Cormican, M., Noone, D., Barry, T., Maher, M., Dawson, M., Gilmartin, J. J. \& Gannon, F. (1994). The ribosomal intergenic spacer region: a target for the PCR based diagnosis of tuberculosis. Tubercle Lung Dis 75, 353-360.

Goguet de la Salmoniere, Y. O., Minh Li, H., Torrea, G., Bunschoten, A., van Embden, J. \& Gicquel, B. (1997). Evaluation of spoligotyping in a study of the transmission of $\mathrm{Myco}$ bacterium tuberculosis. J Clin Microbiol 35, 2210-2214.

Gutiérrez, M., Samper, S., Jiménez, M. S., van Embden, J. D. A., García, J. F. \& Martín, C. (1997). Identification by spoligotyping of a caprine genotype in Mycobacterium bovis strains causing human tuberculosis. J Clin Microbiol 35, 3328-3330.

Hermans, P. W. M., van Soolingen, D., Dale, J. W., Schuitema, A. R. J., MCAdam, R. A., Catty, D. \& van Embden, J. D. A. (1990). Insertion element IS986 from Mycobacterium tuberculosis: a useful tool for the diagnosis and epidemiology of tuberculosis. $J$ Clin Microbiol 28, 2051-2058.

Heym, B., Alzari, P. M., Honoré, N. \& Cole, S. T. (1995). Missense mutations in the catalase-peroxidase gene, $k a t G$, are associated with isoniazid resistance in Mycobacterium tuberculosis. Mol Microbiol 15, 235-245.

Hoop, R. K., Böttger, E. C. \& Pfyffer, G. E. (1996). Etiological agents of mycobacterioses in pet birds between 1986 and 1995. $J$ Clin Microbiol 34, 991-992.

Huitema, H. \& Jaartsveld, F. H. J. (1967). Mycobacterium microti infection in a cat and some pigs. Antonie Leeuwenhoek 33, 209-212.

Imaeda, T. (1985). Deoxyribonucleic acid relatedness among selected strains of Mycobacterium tuberculosis, Mycobacterium bovis, Mycobacterium bovis BCG, Mycobacterium microti and Mycobacterium africanum. Int J Syst Bacteriol 35, 147-150.

Kamerbeek, J., Schouls, L., Kolk, A. \& 8 other authors (1997). Simultaneous detection and strain differentiation of $\mathrm{Myco-}$ bacterium tuberculosis for diagnosis and epidemiology. J Clin Microbiol 35, 907-914.

Karlson, A. G. \& Lessel, E. F. (1970). Mycobacterium bovis nom. nov. Int J Syst Bacteriol 20, 273-282.

Karlson, A. G., Martin, J. K. \& Harrington, R. (1964). Identification of Mycobacterium tuberculosis with one tube of liquid medium. Mayo Clin Proc 39, 410-415.

Kent, P. T. \& Kubica, G. P. (1985). Antituberculous chemotherapy and drug susceptibility testing. In Public Health Mycobacteriology: a Guide for the Level III Laboratory, pp. 159-184. Atlanta: US Department of Health and Human Services, Centers for Disease Control.

Kleeberg, H. H. \& Nel, E. E. (1969). Porcine mycobacterial lymphadenitis. J S Afr Vet Med Assoc 40, 233-250.

Lévy-Frébault, V. V. \& Portaels, F. (1992). Proposed minimal standards for the genus Mycobacterium and for description of new slowly growing Mycobacterium species. Int $J$ Syst Bacteriol 42, 315-323.
Liébana, E., Aranaz, A., Francis, B. \& Cousins, D. V. (1996). Assessment of genetic markers for species differentiation within the Mycobacterium tuberculosis complex. J Clin Microbiol 34, 933-938.

Liébana, E., Aranaz, A., Gonzalez, O., Domingo, M., Vidal, D., Mateos, A., Rodriguez-Ferri, E. F., Dominguez, L. \& Cousins, D. V. (1997). The insertion element IS6110 is a useful tool for DNA fingerprinting of Mycobacterium bovis isolates from cattle and goats in Spain. Vet Microbiol 54, 223-233.

Liu, S. K., Weitzman, I. \& Johnson, G. G. (1980). Canine tuberculosis. J Am Vet Med Assoc 177, 164-167.

Luquin, M., Ausina, V., López-Calahorra, F., Belda, F., GarcíaBarceló, M., Celma, C. \& Prats, G. (1991). Evaluation of practical chromatographic procedures for identification of clinical isolates of mycobacteria. J Clin Microbiol 29, 120-130.

Lutz, B. (1992). Mycobacteriology. Identification tests for mycobacteria. In Clinical Microbiological Procedures Handbook, pp. 3.12. 1-13. Edited by H. D. Eisemberg. Washington, DC: American Society for Microbiology.

Michalak, K., Austin, C., Diesel, S., Bacon, J. M. Zimmerman, P. \& Maslow, J. N. (1998). Mycobacterium tuberculosis infection as a zoonotic disease: transmission between humans and elephants. Emerg Infect Dis 4, 283-287.

Musser, J. M., Kapur, V., Williams, D. L., Kreiswirth, B. N., van Soolingen, D. \& van Embden, J. D. A. (1996). Characterization of the catalase-peroxidase gene ( $k a t G)$ and inh $A$ locus in isoniazidresistant and -susceptible strains of Mycobacterium tuberculosis by automated DNA sequencing: restricted array of mutations associated with drug resistance. $J$ Infect Dis 173, 196-202.

O'Reilly, L. M. \& Daborn, C. J. (1995). The epidemiology of Mycobacterium bovis infections in animals and man: a review. Tubercle Lung Dis 76 (Suppl. 1), 1-46.

Pattyn, S. R., Portaels, F. A., Kageruka, P. \& Gigase, P. (1970). Mycobacterium microti infection in vicuna (Lama vicugna). Acta Zool Pathol Antverp 51, 17-24.

Plikaytis, B. B., Plikaytis, B. D., Yakrus, M. A., Butler, W. R., Woodley, C. L., Silcox, V. A. \& Shinnick, T. M. (1992). Differentiation of slowly growing Mycobacterium species, including Mycobacterium tuberculosis, by gene amplification and restriction fragment length polymorphism analysis. $J$ Clin Microbiol 30, 1815-1822.

Reed, G. B. (1957). Genus Mycobacterium (species affecting warm-blooded animals except those causing leprosy). In Bergey's Manual of Determinative Bacteriology, vol. 2, section 16, p. 1443. Edited by R. S. Breed, E. G. D. Murray \& N. R. Smith. Baltimore: Williams \& Wilkins.

Rogall, T., Flohr, T. \& Böttger, E. C. (1990). Differentiation of Mycobacterium species by direct sequencing of amplified DNA. $J$ Gen Microbiol 136, 1915-1920.

Scorpio, A. \& Zhang, Y. (1996). Mutations in pncA, a gene encoding pyrazinamidase/ nicotinamidase, cause resistance to the antituberculous drug pyrazinamide in tubercle bacillus. Nat Med 6, 662-667.

Scorpio, A., Collins, D., Whipple, D., Cave, D., Bates, J. \& Zhang, Y. (1997). Rapid differentiation of bovine and human tubercle bacilli based on a characteristic mutation in the bovine pyrazinamidase gene. J Clin Microbiol 35, 106-110.

Sherman, D. R., Sabo, P. J., Hickey, M. J., Arain, T. M., Mahairas, G. M., Yuan, Y., Barry, C. E., III \& Stover, K. (1995). Disparate responses to oxidative stress in saprophytic and pathogenic bacteria. Proc Natl Acad Sci USA 92, 6625-6629. 
Snider, W. R. (1971). Tuberculosis in canine and feline populations. Review of the literature. Am Rev Respir Dis 104, $877-887$.

Sola, C., Horgen, L., Maïsetti, J., Devallois, A., Goh, K. S. \& Rastogi, N. (1998). Spoligotyping followed by double-repetitiveelement PCR as rapid alternative to IS6110 fingerprinting for epidemiological studies of tuberculosis. J Clin Microbiol 36, $1122-1124$.

van Soolingen, D., Hoogenboezem, T., de Haas, P. E. W. \& 9 other authors (1997). A novel pathogenic taxon of the Mycobacterium tuberculosis complex, Canetti: characterization of an exceptional isolate from Africa. Int J Syst Bacteriol 47, 1236-1245.

Sreevatsan, S., Escalante, P., Pan, X. \& 11 other authors (1996). Identification of a polymorphic nucleotide in $\operatorname{oxy} R$ specific for Mycobacterium bovis. J Clin Microbiol 34, 2007-2010.

Sreevatsan, S., Pan, X., Stockbauer, K. E., Connell, N. D., Kreiswirth, B., Whittam, T. S. \& Musser, J. M. (1997). Restricted structural gene polymorphism in the Mycobacterium tuberculosis complex indicates evolutionarily recent global dissemination. Proc Natl Acad Sci USA 94, 9869-9874.

Stackebrandt, E. \& Woese, C. R. (1981). The evolution of prokaryotes. In Molecular and Cellular Aspects of Microbial Evolution, pp. 1-31. Edited by M. C. Carlile, J. F. Collins \& B. E. B. Moseley. Cambridge: Cambridge University Press.

Tacquet, A. \& Tison, F. (1961). Nouvelle technique d'isolement des mycobacteries par le laurylsulfate de sodium. Ann Inst Pasteur 100, 676-680.

Takewaki, S.-I., Okuzumi, K., Ishiko, H., Nakahara, K.-I., Ohkubo, A. \& Nagai, R. (1993). Genus-specific polymerase chain reaction for the mycobacterial dnaJ gene and species-specific oligonucleotide probes. J Clin Microbiol 31, 446-450.

Takiff, H. E., Salazar, L., Guerrero, C., Philipp, W., Huang, W. M., Kreiswirth, B., Cole, S. T., Jacobs, W. R. \& Telenti, A. (1994). Cloning and nucleotide sequence of Mycobacterium tuberculosis gyr $A$ and $g y r B$ genes and detecton of quinolone resistance mutations. Antimicrob Agents Chemother 38, 773-780.

Telenti, A., Marchesi, F., Balz, M., Bally, F., Böttger, E. C. \& Bodmer, T. (1993). Rapid identification of mycobacteria to the species level by polymerase chain reaction and restriction enzyme analysis. J Clin Microbiol 31, 175-178.

Thoen, C. O. (1994). Tuberculosis in wild and domestic mammals. In Tuberculosis: Pathogenesis, Protection and Control, pp. 157-162. Edited by B. R. Bloom. Washington, DC: American Society for Microbiology.

Thorel, M. F. (1980). Isolation of Mycobacterium africanum from monkeys. Tubercle 61, 101-104.

Tsukamura, M. (1976). Numerical classification of slowly growing mycobacteria. Int $J$ Syst Bacteriol 26, 409-420.

Uhl, J. R., Sandhu, G. S., Kline, B. C., Cockerill, F. R., III (1996). PCR-RFLP detection of point mutations in the catalaseperoxidase gene (katG) of Mycobacterium tuberculosis associated with isoniazid resistance. In PCR Protocols for Emerging Infectious Diseases, pp. 144-149. Edited by D. H. Persing. Washington, DC: American Society for Microbiology.

Wells, A. Q. \& Oxon, D. M. (1937). Tuberculosis in wild voles. Lancet 1221 .

Wilton, S. \& Cousins, D. (1992). Detection and identification of multiple mycobacterial pathogens by DNA amplification in a single tube. PCR Methods Appl 1, 269-273. 